\title{
Source of the Anti-muillerian Hormone Synthesized by the Fetal Testis: Müllerian-inhibiting Activity of Fetal Bovine Sertoli Cells in Tissue Culture
}

\author{
MARIE-GENEVIÈVE BLANCHARD AND NATHALIE JOSSO $\left({ }^{\left(\frac{x}{3}\right.}\right)$ \\ Unité de Recherches de Génétique Médicale (INSERM), Hôpital des Enfants-Malades, Paris, France
}

\section{Extract}

In order to determine which tubular cells are responsible for the secretion of anti-müllerian hormone (AMH), a method which would yield a pure preparation of fetal Sertoli cells appeared to be desirable. In tissue cultures of postnatal testicular cells, germinal elements remain free-floating in the medium, whereas cells of nongerminal origin attach themselves to the surface of the culture vessel and form a monolayer. If, before cell dissociation, seminiferous tubules are isolated from interstitial tissue, the monolayer formed on the flasks plated with tubular cells is formed only by Sertoli cells. By applying this method to fetal calf testicular tissue, we have obtained separate cultures of fetal Sertoli and interstitial cells and tested müllerian-inhibiting activity.

Tubular cells exhibited a pavement-like pattern, tended to form circular structures, and inhibited the rat fetal müllerian duct after transferral to organ culture conditions. Interstitial cells had a fibroblastic appearance in monolayers, and did not display müllerian-inhibiting activity.

\section{Speculation}

Monolayers arising from the tubular and interstitial compartment of the calf fetal testis, respectively, have been established. As, in the postnatal testis, germ cells do not attach to the walls of culture vessels, it is speculated that the tubular monolayer is formed by Sertoli cells only. Their müllerianinhibiting activity confirms our previous hypothesis that Sertoli cells are the source of the mullerian-inhibiting hormone.

The pioneer work of Jost (8) in 1947 established that the fetal testis is responsible for the masculinization of the genital tract. Androgens, produced by the fetal Leydig cells, maintain the wolffian ducts and virilize the external genitalia. Müllerian ducts, however, are unaffected by androgens, whether in vivo (8) or in vitro (3), and do not regress when placed with fragments of fetal interstitial tissue in organ culture, whereas isolated seminiferous tubules exhibit müllerian-inhibiting activity under the same conditions (6).

In order to determine which tubular cells are responsible for the secretion of anti-müllerian hormone (AMH), it is necessary to separate germinal from Sertoli cells. $\gamma$-Irradiation of fetal testicular tissue maintained in organ culture destroys most germ cells without impairing the müllerian-inhibiting activity of the explants (7), but $\gamma$-rays do not completely eradicate the germ cell line, as approximately $3 \%$ survive exposure to 700 rads. For this reason, a method which would yield a pure preparation of fetal Sertoli cells appeared desirable. Steinberger and Steinberger (16), Kodani (9), Kodani and Kodani (10), and Yamada et al. (19) have shown that in tissue cultures of postnatal testicular cells, germinal elements remain free-floating in the medium, whereas cells of nongerminal origin attach themselves to the surface of the culture vessel and form a monolayer. If, before cell dissociation, seminiferous tubules are isolated from interstitial tissue, the monolayer formed on the flasks plated with tubular cells is formed only by Sertoli cells, free-floating germ cells being eliminated when culture medium is renewed. By application of this method to fetal calf testicular tissue, we have obtained separate cultures of fetal Sertoli and interstitial cells and tested their müllerian-inhibiting activity.

\section{MATERIALS AND METHODS}

Testicular tissue was obtained from 14 calf fetuses, 30-50 $\mathrm{cm}$ in forehead-rump length, approximately $130-155$ days postconception, according to the method of Lindsay (13).

\section{MICRODISSECTION OF TESTICULAR TISSUE}

Microdissection was carried out according to a technique previously described (6) in Eagle's minimum essential medium containing $100 \mathrm{U}$ penicillin and $100 \mu \mathrm{g}$ streptomycin $/ \mathrm{ml}$. To remove adherent interstitial cells, isolated seminiferous tubules were rinsed in phosphate-buffered saline containing $0.25 \%$ trypsin. The cleaned tubules were then incubated for $20 \mathrm{~min}$ at $37^{\circ}$ in a fresh $0.25 \%$ trypsin solution and the cells were dissociated with a Pasteur pipette. After centrifugation at 800 $\mathrm{rpm}$ for $5 \mathrm{~min}$, a pellet of tubular cells was obtained. Interstitial cells were obtained by collecting the microdissection medium under control of the dissecting microscope to avoid tubular fragments. The medium was then centrifuged at $800 \mathrm{rpm}$ for $5 \mathrm{~min}$. Fragments of undissected testicular tissue were also dissociated in trypsin and the resulting cellular suspension was collected by centrifugation.

\section{MONOLAYER CULTURES}

Cultures of the cells derived from seminiferous tubules, interstitial tissue, and whole testis were obtained at $37^{\circ}$ by seeding the cellular suspension in plastic tissue culture flasks in 
Eagle's minimum essential medium supplemented with $10 \%$ fetal calf serum. Leighton tubes were also prepared in each case to allow histologic examination of the monolayer. One week after the initiation of the culture, the coverslip was dipped in methanol and the adherent monolayer was stained with Giemsa. At the same time, the cells grown in the plastic culture flasks were harvested by incubation with $0.25 \%$ trypsin, washed twice with culture medium, and collected by centrifugation.

\section{TRANSFER TO ORGAN CULTURE CONDITIONS}

Transfer was then effected by pipetting the cellular pellet resuspended in $0.3 \mathrm{ml}$ cuiture medium on to a fragment of the vitelline membrane of a hen's egg which was spread out on the grid of an organ culture dish (20). The vitelline membrane was then folded back on top of the cellular suspension and culture medium was added up to the level of the grid. The number of harvested cells did not allow the preparation of more than one culture dish per cell line and per calf fetus. Preliminary experiments showed that in the 3 days which followed the transfer of the cells to organ culture dishes, most of the cells died and the number of those which survived to produce cell colonies was quite unpredictable. On the other hand, if the cells were left in the vitelline membrane for more than 2 weeks, many cells present in the center of the colonies died.

\section{MÜLLERIAN-INHIBITING ACTIVITY}

Activity of the cells was tested 1 week after the transfer by placing castrated reproductive tracts of 14.5-day-old fetal rats on the surface of the vitelline membrane. Three days later, the cultures were fixed in Bouin's fluid. The excess vitelline membrane was trimmed away and the rat reproductive tracts were serially sectioned, together with the testicular cell colonies wrapped in the vitelline membrane. One section out of 10 was stained with schiff-hematoxylin.

Altogether, 34 tracts associated with cells derived from whole testis, 28 associated with tubular cells, and 24 associated with interstitial cells were studied. However, in many cases, the number and viability of the cells contained in the folds of the vitelline membrane did not allow the assessment of their müllerian-inhibiting activity. This could be studied in only 16 colonies derived from whole testicular tissue, in 13 tubular cell colonies, and in 9 interstitial cell colonies (Table 1).

\section{RESULTS}

\section{CELLULAR MORPHOLOGY}

Distinctive morphologic differences were apparent in the various cell lines which formed a monolayer on the coverslip of the Leighton tubes after one week in vitro. Tubular cells, with nuclei containing one or more nucleoli, displayed a pavement-like structure and tended to grow in circles reminiscent of seminiferous tubules (Fig. 1). No cell resembling a gonocyte was seen. Interstitial cell monolayers were formed of elongated cells with a fibroblastic disposition (Fig. 2 ). Both types of cells were represented in cultures derived of undissociated testicular tissue (Fig. 3).

Morphologic differences were not recognized in the cells after transferral to the egg vitelline membrane. Necrotic cells, numerous in the 2 or 3 days which followed the modification

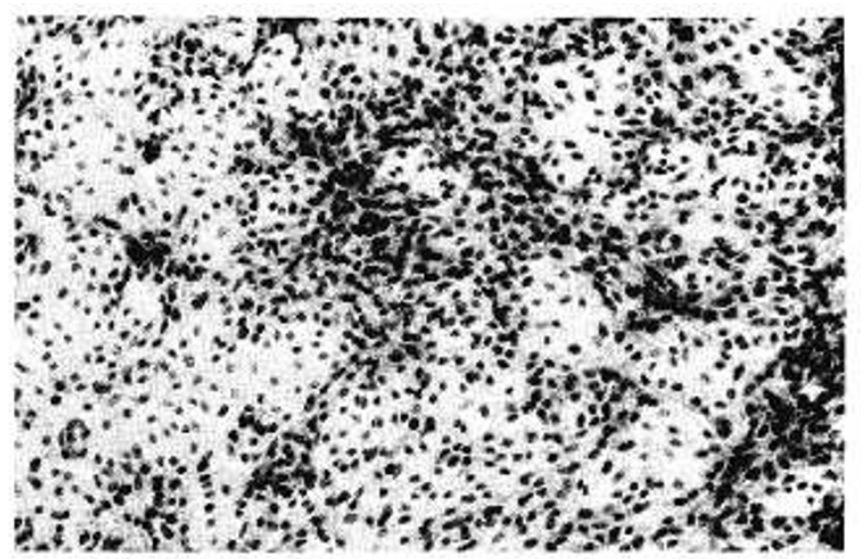

Fig. 1. Aspect of tubular monolayer from $V 284$, grown on coverslip of Leighton tube (Giemsa, $\times$ 90). Note pavement-like growth and tendency to form circular structures reminiscent of seminiferous tubules.

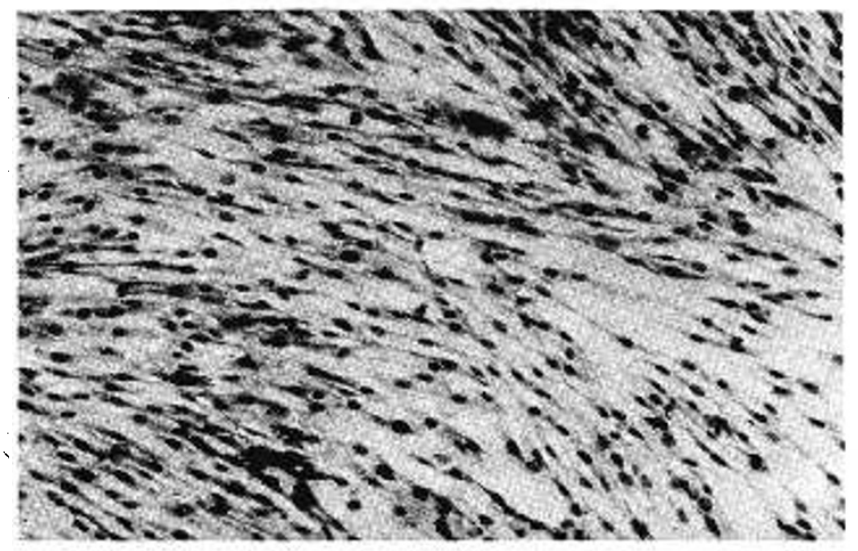

Fig. 2. Aspect of interstitial cell monolayer from $V 284$ grown on coverslip of Leighton tube (Giemsa, $\times$ 90). Note enlongated, fibroblastic pattern of cellular growth.

Table 1.

No. of fetal rat reproductive tracts associated with cells from

\begin{tabular}{|c|c|c|c|c|c|c|c|}
\hline \multirow[b]{2}{*}{ Calf fetus } & \multirow[b]{2}{*}{ Forehead-rump length, $\mathrm{cm}$} & \multicolumn{2}{|c|}{ Whole testis } & \multicolumn{2}{|c|}{ Seminiferous tubules } & \multicolumn{2}{|c|}{ Interstitial tissue } \\
\hline & & Total & With $\mathrm{MI}^{1}$ & Total & With MI & Total & With MI \\
\hline$V 304$ & 48 & 2 & 2 & 1 & 1 & & \\
\hline$V 307$ & 44 & 2 & 2 & 3 & 3 & 1 & 0 \\
\hline$V 312$ & 45 & 1 & 0 & & & & \\
\hline$V 317$ & 43 & 3 & 3 & 3 & 2 & 2 & 0 \\
\hline$V 319$ & 47 & 3 & 3 & 4 & 3 & 2 & 0 \\
\hline$V 324$ & 38 & 2 & 2 & 2 & 1 & 1 & 0 \\
\hline V. 329 & 38 & 3 & 3 & & & 3 & 0 \\
\hline
\end{tabular}

\footnotetext{
${ }^{1} \mathrm{MI}$ : müllerian inhibition.
} 


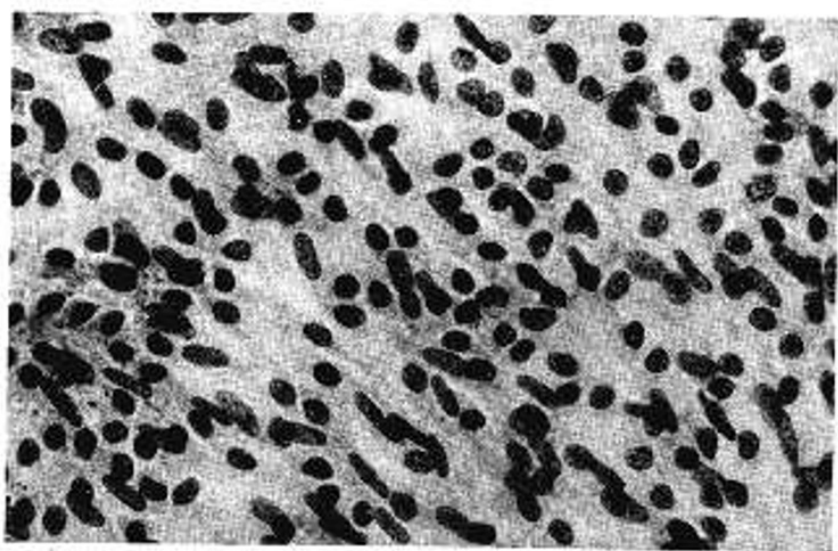

Fig. 3. Aspect of cellular monolayer from undissected testicular tissue of $V$ 284. Giemsa, $\times 200$. Note admixture of elongated and rounded nuclei.

of the culture conditions, had usually disappeared after 10 days. At that time, the folds of the vitelline membrane were covered by one or two layers of testicular cells and in approximately half of the cultures, these developed into colonies of polygonal cells piled on top of one another.

\section{MÜLLERIAN-INHIBITING ACTIVITY OF CELL COLONIES}

Only colonies formed of at least five layers of viable cells will be considered here. Their müllerian-inhibiting activity was reflected by the appearance of the müllerian duct of the rat reproductive tract associated with it for 3 days. No müllerianinhibiting activity was found in the nine interstitial cell colonies studied. Müllerian ducts were normal in all instances (Fig. 4). Müllerian ducts associated with 15 of 16 collonies derived from undissected testicular tissue, and those associated with 10 out of 13 tubular cell colonies were clearly inhibited (Fig. 5), although regression was usually not as marked as when organ, and not tissue cultures, are placed next to the müllerian ducts. Here, müllerian ducts were obliterated only in the anterior segment of the duct but persisted, narrow and surrounded by fibroblasts, in the middle segment of the duct, which is less sensitive to the action of AMH in rats of 14.5 days of fetal development.

\section{DISCUSSION}

Fetal Sertoli cells have been recognized as the most likely source of $\mathrm{AMH}$, on the basis of the unimpaired müllerianinhibiting activity of isolated seminiferous tubules (6) and of testicular explants deprived of germ cells by $\gamma$-irradiation (7). However, a few germ cells survive the latter procedure, and it might be argued that these are necessary to the synthesis of $\mathrm{AMH}$ by seminiferous tubules. For this reason, we wished to study the müllerian-inhibiting activity of a preparation of Sertoli cells uncontaminated by germ cells. Monolayer cultures were therefore established from the tubular and interstitial compartment of fetal calf testicular tissue. Tubular cells exhibited a pavement-like pattern, tended to form circular structures, and inhibited the rat fetal müllerian duct after transferral to organ culture conditions. Interstitial cells had a fibroblastic appearance in monolayers, and did not display müllerian-inhibiting activity.

Because of the report by Steinberger and Steinberger (16, 17) that gonocytes do not attach themselves to the walls of culture vessels, we assume that the monolayer we obtained from the tubular compartment of the fetal calf testis is formed by Sertoli cells. Few testicular cell cultures have been performed in the fetus, and in none was separation of seminiferous tubules from interstitial tissue previously carried out. Abraham (1), in monolayer cultures of trypsin-dissociated fetal chick testes, observed structures reminiscent of seminiferous tubules rather similar to those seen in our own tubular monolayers.

In the postnatal testis, the nature of the cellular monolayer depends on the type of cells from which the culture is initiated, and also on the culture method used. Lee (12), on the basis of histochemical data, considered that monolayers obtained from whole juvenile chick testicular tissue were composed by aggregates of interstitial cells. If seminiferous tubules are isolated before the cell culture procedure, Sertoli cell monolayers are formed on culture vessels seeded with a cellular suspension (19), but if the intact seminiferous tubules are explanted on coverslips $(2,11)$, the cellular outgrowth is formed by myoid cells of the peritubular sheath.

Müllerian-inhibiting activity of cell monolayers cannot be studied and therefore a switch to organ culture conditions was necessary, in spite of the high cellular mortality entailed by this procedure. An egg vitelline membrane, which is known to be permeable to AMH (5), was used to protect cells from total lysis, on the basis of the results published by Wolff and Wolff (18), who used egg vitelline membrane to culture cancer cells. It is probable that the cellular colonies which developed in the vitelline membrane arose from the division of a few surviving cells and not from the reassociation phenomena described by Moscona and Moscona (14) and Steinberg (15) in populations of dissociated embryonic cells, especially as evidence of testicular neohistogenesis was lacking after transfer of the cells to the new environment.

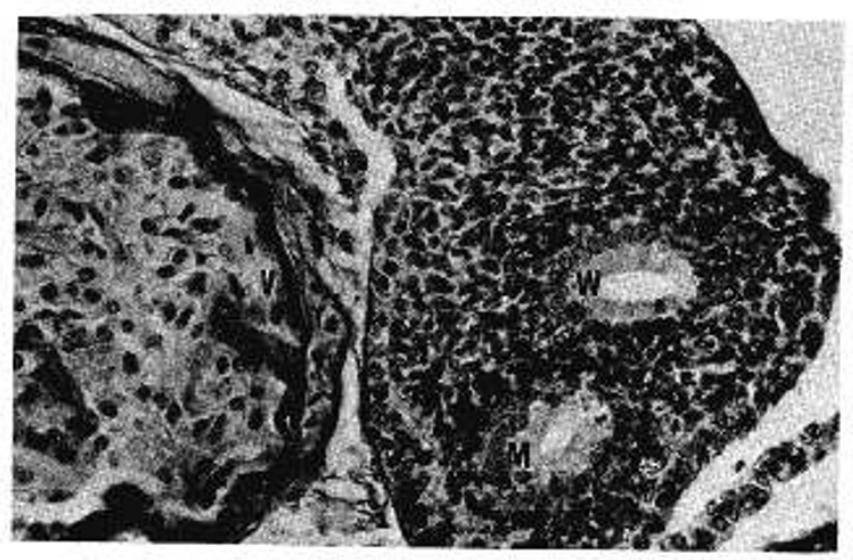

Fig. 4. Fetal rat reproductive tract associated with interstitial cell colony from $V$ 329. Müllerian duct is maintained (periodic acid-schiffhematoxylin, $\times$ 200). $M$ : müllerian duct; $W$ : wolffian duct; $V$ : vitelline membrane.

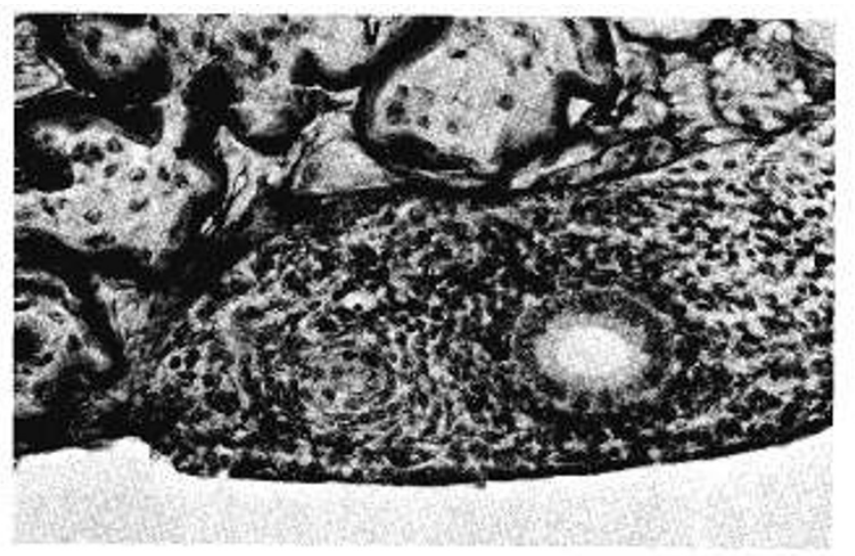

Fig. 5. Fetal rat reproductive tract associated with tubular cells from $V$ 304. The müllerian duct is inhibited (periodic acid-schiff-hematoxylin, X 200). $M$ : müllerian duct; $W$ : wolffian duct; $V$ : vitelline membrane. 
The fact that müllerian-inhibiting activity was recognized only in colonies originating from tubular cells or from undissected testicular tissue is consistent with the hypothesis that Sertoli cells are the source of AMH.

\section{SUMMARY}

Separate Sertoli and interstitial cell monolayers were obtained from the fetal calf testis after prior isolation of the seminiferous tubules by microdissection. After harvesting, the cells composing the monolayers were transferred to organ culture dishes by pipetting the cellular suspension onto a fragment of egg vitelline membrane. The müllerian-inhibiting activity of the cell colonies formed in the vitelline membrane sac was tested by association to castrated 14-day-old fetal rat reproductive tracts. Müllerian-inhibiting activity was found only in the colonies derived from whole testicular tissue or its tubular compartment, but not in colonies derived from interstitial cells.

\section{REFERENCES AND NOTES}

1. Abraham, M.: Processus de réorganisation dans le aggrégats formés par les cellules des gonades dissociées d'embryon de poulet. Arch. Anat. Microscop. Morph. Exp., 49: 333 (1960).

2. Bressler, R. S., and Ross, M. H.: On the character of the monolayer outgrowth and the fate of the peri-tubular myoid cells in cultured mouse testis. Exp. Cell Res., 78: 295 (1973).

3. Josso, N.: Effect of testosterone and of some of its 17-hydroxylated metabolites on the müllerian duct of the foetal rat, in organ culture. Eur. J. Clin. Biol. Res, 16:694 (1971).

4. Josso, N.: Evolution of the müllerian-inhibiting activity of the human testis. Effect of fetal, peri-natal and post-natal human testicular tissue on the müllerian duct of the fetal rat in organ culture. Biol. Neonate, 20:368 (1972).

5. Josso, N.: Permeability of membranes to the müllerian-inhibiting substance synthesized by the human fetal testis in vitro: A clue to its biochemical nature. J. Clin. Endocrinol., 34: 265 (1972).

6. Josso, N.: In vitro synthesis of müllerian-inhibiting hormone by seminiferous tubules isolated from the calf fetal testis. Endocrinology, 93: 829 (1973).

7. Josso, N.: Müllerian-inhibiting activity of human fetal testicular tissue deprived of germ cells by in vitro irradiation. Pediat. Res., 8: 755 (1974).

8. Jost, A.: Recherches sur la différenciation sexuelle de l'embryon de lapin. 3. Rôle des gonades foetales dans la différenciation sexuelle somatique. Arch. Anat. Microscop. Morphol. Exp., 36: 271 (1947).

9. Kodani, M.: Long term in vitro maintenance of mammalian spermatogenesis. Genetics, 47: 965 (1962).

10. Kodani, M., and Kodani, K.: The in vitro cultivation of mammalian Sertoli cells. Proc. Nat. Acad. Aci., 56: 1200 (1966).

11. Kretser, D. M. de, Catt, K. J., Dufau, M. L., and Hudson, B.: Studies on rat testicular cells in tissue culture. J. Reprod. Fert., 24: 311 (1971).

12. Lee, H. H.: Reaggregation and reorganization of juvenile chicken testicular cells in vitro. Develop. Biol., 24: 322 (1971).

13. Lindsay, F. E. F.: Observations on the loci of ossification in the prenatal and neonatal bovine skeleton. III. The vertebral column. Brit. Vet. J., 128: 121 (1972).

14. Moscona, A., and Moscona, H.: The dissociation and aggregation of cells from organ rudiments of the early chick embryo. J. Anat., 86: 287 (1952).

15. Steinberger, M. S.: Reconstruction of tissues by dissociated cells. Science, 141: 401 (1963).

16. Steinberger, A., and Steinberger, E.: In vitro culture of rat testicular cells. Exp. Cell Res., 44: 443 (1966).

17. Steinberger, A., and Steinberger, E.: Tissue culture of male mammalian gonad. Advan. Tissue Cult., 5: 17 (1970).

18. Wolff, E., and Wolff, E.: Le rôle du mésonéphros de l'embryon de poulet dans la nutrition des cellules cancéreuses. II. Etude par la méthode de la membrane vitelline. J. Embryol. Exp. Morphol., 9: 678 (1961).

19. Yamada, M., Yasue, S., and Matsumoto, K.: Formation of 5 $\alpha$-reduced products from testosterone in vitro by germ cells from immature rats. Acta Endocrinol., 71: 393 (1972).

20. Falcon Plastics, Oxnard, Calif.

21. We are grateful to Anne Dellon, Dinh Tran, and Jacqueline Campargue for techinical assistance, to Miss G. Acker and her staff for breeding the pregnant rats used in this study, and to Miss Andrée l'Horisson for her able secretarial skill.

22. This research was supported in part by Grant no. 71-7-3028 of the Délégation Générale à la Recherche Scientifique et $T$ echnique.

23. Requests for reprints should be addressed to: N. Josso, M.D., Unité de Recherches de Génétique Médicale (INSERM), Hôpital des Enfants-Malades, 149 Rue de Sèvres, 75730 Paris Cedex 15, France.

24. Accepted for publication July 18, 1974. 